\title{
The Relationship between Both Accounting Earnings and Cash Flows, and Cash Dividends for Commercial Banks Operating in Jordan
}

Submitted 08/04/20, $1^{\text {st }}$ revision 28/07/20, $2^{\text {nd }}$ revision 10/08/20, accepted 18/08/20

\author{
Abdallah K. Atieh ${ }^{1}$, Abdulrazzak K. Alshehadeh ${ }^{2}$, Mohammed L. Ashour ${ }^{3}$ \\ Abstract:
}

Purpose: The paper aims to examine the relationship between both accounting earnings and cash flows from operating, investing, and financing activities from one side, and cash dividends from another side for commercial banks operating in Jordan.

Design/Methodology/Approach: In this paper, we apply the analytical approach to test hypotheses using the published financial statements for the period (2010-2018). The data is analyzed by employing the statistical program (SPSS). Researchers mainly use the (OLS) multiple linear regression approach to analyzing the study sample's financial data, which consists of (13) Jordanian commercial Banks listed on the Amman Stock Exchange.

Findings: The study concludes that there is no relationship between changes in operating, investing, and financing cash flows and changes in cash dividends of commercial banks operating in Jordan. However, there is a statistically significant relationship between changes in earnings and changes in cash dividends. Furthermore, the results show that the size of liabilities affects only the relationship between accounting earnings changes and changes in cash dividends.

Practical Implications: Jordanian commercial banks should logically link cash flows and accounting earnings when making cash dividend decisions, as relying on cash flows is important in knowing their ability to fulfill obligations and determining liquidity.

Originality/Value: Several controversial studies have examined the ability of earnings and cash flows to judge non-financial firms' performance. The value of this paper is to report the first direct test of the link between both accounting earnings and cash flows from operating, investing, and financing activities from one side, and cash dividends from another side for commercial banks operating in Jordan, and the effect of liabilities on this relationship.

Keywords: Accounting earnings, cash flows, cash dividends, commercial banks.

JEL Code: M4, M41, G10.

Paper Type: Research study.

ISSN: 2241-4754, H index 10, Q3.

Acknowledgement: This work was supported by the Abdul Hameed Shoman FoundationJordan (grant number 10/2018).

${ }^{1}$ Corresponding author, Al-Zaytoonah University of Jordan, a.atieh@zuj.edu.jo;

${ }^{2}$ Al-Zaytoonah University of Jordan, abdulrazzaqsh@zuj.edu.jo;

${ }^{3}$ Al-Zaytoonah University of Jordan, m.ashour@zuj.edu.jo; 
254

\section{Introduction}

Several controversial studies have examined the ability of income statement indicators based on accruals to judge companies' current and future performance. This controversy within the academic research and the economic community has escalated with the increase in many companies' bankruptcies, as their income statements revealed a high net income, while they faced a deficit in their cash liquidity. None of the income statement, financial position statement, and cash flow statement competes for each other, but rather they interrelate and complement each other.

The issue of cash dividends is widespread throughout the accounting literature and studying factors that affect dividends has long been recognized (Charitou, 2000; Rose, 2003). Hence, this study is conducted to show the relationship between both changes in cash flows from operating, investing, and financing activities and changes in accounting earnings from one side, and cash dividends from another side in commercial banks operating in Jordan.

The study's results should be important for all parties that have a direct or indirect interest in commercial banks operating in Jordan, including present and potential investors, financial analysts, capital markets, and commercial banks, to understand and formulate dividend policies.

\subsection{Study Problems and Questions}

The fact that companies achieve high profits does not necessarily mean that they realize high cash flows. When the researchers reviewed some Jordanian commercial banks' financial statements listed on the Amman Stock Exchange (ASE), there was a clear weakness in cash dividends per share, even though the financial statements of these banks show good accounting earnings that fit with the size of their investments. Based on this, the study problem lies in finding answers for the following two dimensions. The first dimension relates to the generally accepted accounting fact that manipulating accruals should inevitably harm profits disclosed; this would necessarily lead to an opposite effect on cash dividends, so net income figure according to the accrual basis could not be used as an indication of the availability of cash to pay dividends to shareholders. Many studies confirm a high number of bankrupted companies despite achieving good annual profits while facing a deficit in cash liquidity (Yeo, 2018).

The second dimension relates to the relationship between cash flows as a performance measure of banks and cash dividends because cash flows could be used as an indicator to judge the ability to distribute cash dividends. A bank might have cash capacity to fulfill its obligations, although it is not profitable (Sindhu, 2014; Tijjani, 2016; Ningsih and Soesetio, 2018). The study problems can be formulated by asking the following main questions: 
1. Is there a relationship between changes in cash flows and changes in cash dividends for commercial banks operating in Jordan?

2. Is there an effect of liabilities size on the relationship between changes in cash flows and changes in cash dividends for commercial banks operating in Jordan?

3. Is there a relationship between changes in accounting earnings and changes in cash dividends for commercial banks operating in Jordan?

4. Is there an effect of liabilities size on the relationship between changes in accounting earnings and changes in cash dividends for commercial banks operating in Jordan?

\subsection{Study Motivation and Contribution}

The banking industry is the heart of developing countries' economies because it plays a vital role in advancing economic development. The banking sector has entered a new era and has shifted from its traditional work of attracting deposits and lending them to investors into creating new investment opportunities. This transformation has motivated the emergence of this industry as an attractive destination for many investors. Thus, in most countries, the banking sector represents the main artery in their economies, as it occupies the forefront among other economic sectors.

Accounting data presented in companies' financial statements play a fundamental role in guiding investors and evaluating their future trends such as buying, selling, or increasing their shares. Consequently, this study seeks to achieve a more in-depth understanding of variables that govern the relationship between each of earnings and cash flows with dividends of commercial banks operating in Jordan. In practice, the process of making any investing or financing decision should be based on analyzing the financial situation of companies, so investors are concerned with the ability of companies to generate cash flows as this affects their share prices and dividends. Creditors are interested in borrowers' cash flows in the short term, and borrowers should efficiently plan and manage their cash flows to determine the value of paid dividends and the need for external financing.

The issue of dividend policies and factors affecting the ability to distribute cash for shares in Jordanian commercial banks is one of the core issues related to these financial institutions' economies and one of the most important financial decisions that result in maximizing shareholders' wealth in financial markets. From this perspective, this study gains its importance from the significance of this study's expected results by finding the scientific and logical justification for the relationship between both changes in accounting earnings and cash flows and dividends of commercial banks in Jordan. This is of interest to all parties that have an interest directly and indirectly in economies of these banks from investors, financial analysts, shareholders, capital markets, and managers of banks. The results of this study would be a crystallization of the nature of the relationship between accrual-based performance measures and 
cash-based performance measures, and what information each measure could provide to meet the needs of these parties.

Several studies confirm that investors pay higher prices for shares with high dividends, and low dividends negatively affect stock prices in financial markets. Earnings play a fundamental role in determining dividends. The results of this study would logically justify from an accounting perspective the relationship between both changes in earnings, cash flows from operating, investing, and financing activities, and cash dividends for commercial banks operating in Jordan.

The results of this study are also expected to get scientific answers based on accounting and statistical justifications for the controversy over the relationship between changes in accounting earnings and dividends, as managers' control over a part of accounting accruals through, for example, adjusting entries makes it possible to manipulate earnings to serve managers' own goals. This influences financial results and, thus, the ability to distribute dividends.

This study's results would assist different parties in determining which of the metrics has the greatest impact on dividends. Additionally, this study is expected to assist the regulatory bodies in Jordan to control the use of accounting choices within the framework of the primary goal of accounting, which is to provide users with useful information for decision making. This study would be an addition to accounting research, as results could contribute to opening new horizons for research issues of earnings quality and its relationship with the ability to pay dividends.

The practical implication of this study stems from the fact that it helps different parties to understand and formulate dividend policies. According to the best knowledge of researchers, this study is one of the few studies that focuses on understanding the dynamics and not just testing the direction of the relationship between both earnings and cash flows, and dividends.

\subsection{Study Objectives}

This study aims to determine the most influential measure of performance by comparing performance-measures based on accounting earnings and those based on cash flows and their relationship with the ability to pay dividends in commercial banks operating in Jordan. This should help current and prospective investors measure performance, which is achieved during the fiscal period, and determine the ability of those accounting measures in judging dividends. Specifically, this study aims to achieve the following goals:

1. Examining the relationship between changes in cash flows and changes in cash dividends for commercial banks operating in Jordan. 
2. Testing the effect of liabilities size on the relationship between changes in cash flows and changes in cash dividends for commercial banks operating in Jordan.

3. Exploring the relationship between changes in accounting earnings and changes in cash dividends for commercial banks operating in Jordan.

4. Investigating the effect of liabilities size on the relationship between changes in accounting earnings changes and changes in cash dividends for commercial banks operating in Jordan.

\subsection{Study Hypotheses}

H01: There is no statistically significant relationship between changes in cash flows and changes in cash dividends for commercial banks operating in Jordan.

H02: There is no statistically significant effect of liabilities size on the relationship between changes in cash flows and changes in cash dividends for commercial banks operating in Jordan.

H03: There is no statistically significant relationship between change in accounting earnings and changes in cash dividends for commercial banks operating in Jordan.

H04: There is no statistically significant effect of liabilities size on the relationship between changes in accounting earnings and changes in cash dividends for commercial banks operating in Jordan.

\section{Theoretical Framework and Literature Review}

When analyzing liquidity, the cash flow statement's information is more reliable than that provided by financial position statement and income statement, as financial position statement provides static information at a specific date. In contrast, income statement contains some non-cash items such as depreciation, accrued revenues, and expenses. On the contrary, the cash flows statement records changes in other financial statements and clearly sheds light on what is important for shareholders to identify available cash from operating, investing, and financing activities. The research documented a relationship between the form in which accounting information is presented and decisions made by interested parties (Oroud et al., 2017).

It is highly possible that there would be no match between net income in income statements and operating cash flows in cash flow statements due to non-cash expenses such as depreciation (Khanji and Siam, 2015). Operating cash flows could be greater or less than net income. A company might achieve a net profit with negative operating cash flows due to, for example, the existence of a large volume of credit sales that is not collected (Bala, 2017; Kourtis et al., 2019). It is a common accounting fact that manipulating accruals would certainly have an adverse effect on disclosed earnings, which could lead to an opposite effect on cash dividends. Therefore, according to the 
accrual basis, net income figures should not be used as an indicator of cash available to pay dividends to investors.

The cash flow statement highlights the divergence between accrual-basis accounting and cash-basis accounting, as it converts net income in income statements from an accrual basis to a cash basis. Ratios of the cash flow statement give a clearer picture of solvency. As lenders, banks prefer to employ cash flow statements of borrowers when banks make credit decisions and evaluate risks. Studies demonstrated that the accuracy of assessing borrowers' solvency differs among lending managers of commercial banks who use cash flow data compared to those who use earnings data (Sharma and Iselin, 2003; Curtis et al., 2020).

Cash flow statement is more important for commercial banks than income statements and financial position statements because cash flows are used to evaluate liquidity, service debt (i.e., pay interest and debt installments), and pay dividends (Kaddumi and Al-Kilani, 2006; Al-Habbash, 2006). Many studies in local and global environments examine the relationship between earnings and cash flows from one side, and returns, dividends, and financial performance from another side. Dergham and Dergham (2009) indicated a statistically significant relationship between earnings per share and both operating and financing cash flows but not investing cash flows in Palestinian banks. The results of Hamidi (2014) showed that there is a statistically significant effect of the ratio of operating cash flows to short-term liabilities on the value of Iraqi banks. Al-Zahrani and Al-Debi'e (2016) found that both earnings levels and changes are appropriate to explain changes in Saudi companies' stock prices. Hafsi (2017) concluded a statistically significant relationship between the dividend policy (represented by dividends per share and earnings per share) and the market value of shares of companies listed on the Dubai Financial Market.

Fah and Mohamad (2008) showed that cash flow changes measured over one-year intervals do not affect Malaysian companies' share prices. Cash flows have no information content for share prices in the annual and medium windows tests; however, cash flows do have information in the short window tests with incremental information content beyond earnings, but investors still prefer to use earnings announcements for share price valuation.

Charitou (2000) extended the US study of DeAngelo et al. (1992), who did not examine the effect of operating cash flows on dividend reduction decisions. Charitou employed data of (529) Japanese industrial firms during (1984-1995), and he found that cash flows have extra explanatory power over losses and earnings in explaining dividend changes for firms with established earnings and dividend records. $\mathrm{He}$ defined those firms as firms, which report positive dividends and earnings for successive five years. Additionally, Charitou reported that the relative explanatory power of earnings alone (i.e., without cash flows in the model) is more than that of cash flows alone, and the incremental information content of earnings beyond cash 
flows (i.e., earnings and cash flows together in the model) is also higher than that of cash flows beyond earnings.

Bani-Khaled (2012) indicated that the cash flows statement significantly impacts interpreting market value per share of Jordanian commercial banks. It was found that operating cash flow is the most influential variable before and after the global financial crisis. Conversely, there is no significant effect of operating, investing, and financing cash flows during the global financial crisis (years 2007 and 2008). Atieh and Hussain (2012) argue that accruals data reflect judgments and estimates of managers. They tested whether accruals data provide users additional insight into the firm's dividends beyond cash flows alone. The authors employed the regression analysis to examine the relative ability of earnings, cash flows, and accruals to explain dividends. It is found that cash flows and accruals (disaggregating earnings) possess significant explanatory power for dividends, indicating that, on average, UK financial statements provide users with improved insight beyond that is conveyed by cash flows alone.

Al-Rjoub et al. (2013) examined the relationship between earnings per share and market stock returns. They found that the ability of changes and levels of earnings per share does not explain more than $9.9 \%$ of market stock returns of industrial companies listed on the Amman Stock Exchange. The use of more than one measurement of earnings enhances the ability to interpret market stock returns and reduce bias errors in earnings measurement. Yamrali et al. (2014) indicated a positive and significant relationship between the operating profits and abnormal stock returns of initial public offering in the Tehran Stock Exchange; however, there is a weak association between operating cash flows and abnormal returns. Olugbenga and Atanda (2014) showed a significant relationship between accounting information and share prices of companies listed on the Nigerian Stock Exchange. Information on earnings, dividends, equity book values, and cash flows can be used to predict share prices. This implies that accounting information serves as a guide to investors' investment decisions.

Khanji and Siam (2015) indicated a limited effect of operating, investing, and financing cash flows on Jordanian commercial banks' share market values. Consequently, more concern is needed regarding cash flow behavior when assessing share prices. Hortamani and Behnam (2015) concluded that the effect of cash flows on shares market value is significantly positive as high cash flows lead to reduce liquidity risk. The results also documented the same effect of operating income as that of cash flows. High operating income leads to increasing demand for shares; consequently, this increases shares market value.

Nazemi and Abdoli (2015) demonstrated that earnings and operating cash flows (before the restatement of financial statements) are related to stock returns, although they become negatively related to the stock return after financial statement restatements. The difference between before and after restatements is more evident for earnings. Sindhu (2014) indicated that results are insignificant in a simple regression of free cash flow and dividend. The model of firm size moderator is also 
insignificant for the relationship between free cash flows and dividends. The same results are concluded across different periods.

Kodithuwakku (2016) found a positive relationship between selected firm-specific factors of dividend per share, earnings per share, net assets value per share, and stock price. Foerster et al. (2017) found that while various income statement-based measures (such as gross profits-to-assets) have the power to predict stock returns, direct-method cash-flow measures have even stronger power. Results are robust to investment horizons and across risk factors, including controlling for sector differences. They also showed that, in addition to operating cash flow, cash taxes and capital expenditures provide incremental stock returns' predictive power.

Oroud et al. (2017) found that the cash flows have a statistically significant effect on Jordanian companies' share prices listed on the Amman Stock Exchange. Operating, investing, and financing cash flows together explain around (13\%) variations in share prices. However, whereas operating cash flows have a positive effect on share prices, the effect of financing cash flows is negative. Kadioglu and Yilmaz (2017) revealed a negative significant correlation between dividends per share and free cash flows. Likewise, a significant inverse relationship is found between leverage and free cash flows.

Bala (2017) showed no statistically significant relationship between operating, investing, and financing cash flows individually or jointly and stock returns of financial investment banks on the Khartoum Stock Exchange. Al-Laban et al. (2018) indicated a predictive ability for earnings before interest and tax, operating cash flows, dividend payout, and capital expenditures to predict free cash flows of non-financial firms listed on the Iraqi Stock Exchange. Also, there is a moderating role for the dividend payout predictive ability. Yeo (2018) found that free cash flow is a determinant of investment and dividends in the shipping industry. Higher free cash flow leads firms to raise investment and reduce dividends. Additionally, the use of debt alleviates overinvestment. Moreover, he reported that shipping firms' free cash flow of different sizes influences investment and dividends.

\section{Study Methodology}

This study investigates the relationship between changes in earnings and cash flows and changes in cash dividends of Jordanian commercial banks operating in Jordan during the period (2010-2018). After that, the study examines the effect of liabilities size on the previous relationship.

The study population consists of (24) banks operating in Jordan. A deliberate sample of all (13) Jordanian commercial banks listed on the Amman Stock Exchange (ASE) is selected. This study uses panel data collected from ASE. The study uses the Statistical Package for Social Sciences (SPSS) to analyze the study data. The study is 
based on using descriptive analysis tests, multicollinearity test by employing Pearson correlation, and the linear regression method to test hypotheses.

\subsection{Study Variables}

This section contains the definition of variables and their symbols in the study models. They are as follows (Yamrali et al., 2014; Al-Zahrani and Al-Debi'e, 2016; Bala, 2017; Oroud at al., 2017):

$\triangle$ OCFit: operating cash flows change for bank $i$ for year $t$ (independent variable) $\Delta \mathrm{OCF} i t=(\mathrm{OCF} i t-\mathrm{OCF} i, t-1) / \mathrm{OCF} i, t-1$

$\Delta \mathrm{ICF}$ it: investing cash flows change for bank $i$ for year $t$ (independent variable) $\Delta \mathrm{ICF} i t=(\mathrm{ICF} i t-\mathrm{ICF} i, t-1) / \mathrm{ICF} i, t-1$

$\Delta \mathrm{FCF} i$ : financing cash flows change for bank $i$ for year $t$ (independent variable) $\Delta \mathrm{FCF} i t=(\mathrm{FCF} i t-\mathrm{FCF} i, t-1) / \mathrm{FCF} i, t-1$

$\Delta$ ERit: earnings change for bank $i$ for year $t$ (independent variable) $\Delta \mathrm{ER} i t=(\mathrm{ER} i t-\mathrm{ER} i, t-1) / \mathrm{ER} i, t-1$

$\Delta \mathrm{DV} i t$ : dividends change for bank $i$ for year $t$ (dependent variable) $\Delta \mathrm{DV} i t=(\mathrm{DV} i t-\mathrm{DV} i, t-1) / \mathrm{DV} i, t-1$

Lit: logarithm of liabilities for bank $i$ for year $t$ (control variable).

Operating cash flows represent cash flows resulting from the main operational activities and all regular operations representing the operating cycle of a bank, or they represent cash flows resulting from the main activities to generate revenues in a bank. Operating cash flows equal cash revenues minus cash expenses (Garrison et al., 2018). Investing cash flows represent all investment activities related to acquiring or disposing of non-current assets. Investing cash flows equal investing cash inflows minus investing cash outflows.

Financing cash flows represent all financing activities related to obtaining or paying non-current liabilities and stockholders' equity. Financing cash flows equal financing cash inflows minus financing cash outflows (Garrison et al., 2018). Earnings are net income after taxes. Earnings are net income before taxes minus annual taxes and previous years' taxes in addition to rewards of Board of Directors' members and universities and scientific research fees.

Dividends represent the value of what a shareholder gets from a bank's cash dividends during the financial period. Dividends are calculated through the ratio of cash dividends distributed to the number of subscribed shares. Liabilities are total current and non-current liabilities. 


\subsection{Study Models}

The relationship between changes in cash flows and changes in cash dividends for commercial banks operating in Jordan is examined using the following model:

$$
\Delta \mathrm{DV} i t=\alpha+\beta_{1} \Delta \mathrm{OCF} i t+\beta_{2} \Delta \mathrm{ICF} i t+\beta_{3} \Delta \mathrm{FCF} i t+\varepsilon_{i t}
$$

The effect of liabilities size on the relationship between changes in cash flows and changes in cash dividends for commercial banks operating in Jordan is examined using the following model:

$$
\Delta \mathrm{DV} i t=\alpha+\beta_{1} \mathrm{Lit}+\beta_{2} \Delta \mathrm{OCF} i t+\beta_{3} \Delta \mathrm{ICF} i t+\beta_{4} \Delta \mathrm{FCF} i t+\varepsilon_{i t}
$$

The relationship between changes in accounting earnings and changes in cash dividends for commercial banks operating in Jordan is examined using the following model:

$\Delta \mathrm{DVit}=\alpha+\beta_{1} \Delta \mathrm{ER} i t+\varepsilon_{i t}$

The effect of liabilities size on the relationship between changes in accounting earnings and changes in cash dividends for commercial banks operating in Jordan is examined using the following model:

$\Delta \mathrm{DV} i t=\alpha+\beta_{1}$ Lit $+\beta_{2} \Delta \mathrm{ER} i t+\varepsilon_{i t}$

where: $i$ : bank; $t:$ year; $\Delta$ : change from year $t-1$ to year $t ; D V$ : dividends; OCF: operating cash flows; ICF: investing cash flows; FCF: financing cash flows; ER: earnings; L: logarithm of liabilities; $\alpha$ : constant; $\beta 1$ to $\beta 4$ : variables coefficients; $\varepsilon$ : random error.

\subsection{Diagnostic Analysis}

The study uses the multicollinearity test by Pearson correlation to determine if the study data suffer from any econometric issues (Baltagi, 2008; Gujarati and Porter, 2009; Baltagi et al., 2010). Table 1 shows the result of the Pearson correlation among changes in cash flows variables where the study measure changes in cash flows via three indicators, namely changes in operating cash flows $\triangle \triangle O C F)$, changes in investing cash flows $(\triangle \mathrm{ICF})$, and changes in financing cash flows $(\triangle \mathrm{FCF})$. Gujarati and Porter (2009) claimed that the multicollinearity issue appears when the correlation coefficient between two variables is more than (0.80). The results show that all Pearson correlation coefficients are less than $(0.80)$, so the study's regression model does not suffer from the multicollinearity problem. It is worth noting that Table 1 indicates that there are negative relationships between $\triangle \mathrm{OCF}$ and $\triangle \mathrm{ICF}$, as well as $\triangle \mathrm{ICF}$ and $\triangle \mathrm{FCF}$. However, there is a positive relationship between $\triangle \mathrm{OCF}$ and $\triangle \mathrm{FCF}$. 
Table 1. Pearson Correlation Coefficients

\begin{tabular}{llll} 
Variables & $\Delta \mathrm{OCF}$ & $\Delta \mathrm{ICF}$ & $\Delta \mathrm{FCF}$ \\
\hline$\Delta \mathrm{OCF}$ & 1.000 & & \\
$\Delta \mathrm{ICF}$ & -0.123 & 1.000 & \\
$\Delta \mathrm{FCF}$ & 0.125 & -0.023 & 1.000 \\
\hline
\end{tabular}

Source: Authors.

\subsection{Descriptive Analysis}

This study removes the outliers and extreme values to improve the study results' reliability by analyzing the remaining data. Then, this study uses descriptive analysis tests (i.e., mean, and standard deviation). The study also uses a one-sample t-test to identify significant differences between variables data of Jordanian commercial banks during the study period. If the significant value (sig.) is more than (0.05), there are no significant differences. Otherwise, there are significant differences. Table 2 indicates that the mean value for $\triangle \mathrm{OCF}$ is (-1.159) with a standard deviation (2.096). Regarding the $\triangle \mathrm{ICF}$ variable, the mean is $(-0.614)$, with a standard deviation $(1.823)$. The mean of $\triangle \mathrm{FCF}$ during the study period is (-0.528) with a standard deviation (1.617). Additionally, the mean of $\triangle E R$ is $(0.031)$ with a standard deviation $(0.288)$. About $\triangle \mathrm{DV}$, the mean is $(0.034)$ with a standard deviation $(0.312)$. The mean of the liabilities size variable's logarithm is (15.294) with a standard deviation (7.094).

The results of the t-test indicate that there are significant differences among the data of $\triangle \mathrm{OCF}, \triangle \mathrm{ICF}$, and $\triangle \mathrm{FCF}$, as well as $\mathrm{L}$ of Jordanian commercial banks during the study period. Simultaneously, there are no significant differences among the data of $\triangle \mathrm{ER}$ and $\triangle \mathrm{DV}$ of Jordanian commercial banks stocks during the study period. This means a gap (deviation) in cash flows and liabilities among Jordanian commercial banks during the study period.

Table 2. Descriptive Analysis Tests

\begin{tabular}{lllll} 
Variables & Mean & Standard deviation & $\boldsymbol{T}$ & Sig. \\
\hline $\mathbf{\Delta O C F}$ & -1.159 & 2.096 & -5.636 & 0.000 \\
$\mathbf{\Delta} \mathbf{I C F}$ & -0.614 & 1.823 & -3.434 & 0.001 \\
$\mathbf{\Delta F C F}$ & -0.528 & 1.617 & -3.328 & 0.001 \\
$\mathbf{\Delta E R}$ & 0.031 & 0.288 & 1.111 & 0.269 \\
$\mathbf{\Delta D V}$ & 0.034 & 0.312 & 1.126 & 0.263 \\
$\mathbf{L}$ & 15.294 & 7.094 & 21.987 & 0.000 \\
\hline
\end{tabular}

Source: Authors.

\subsection{Regression Model Analysis}

The study uses the linear regression analysis to test the study hypotheses. The following paragraphs show the results of each hypothesis: 
H01: There is no statistically significant relationship between changes in cash flows and changes in cash dividends for commercial banks operating in Jordan.

There are three indicators to measure changes in cash flows in this study, namely $\triangle \mathrm{OCF}, \triangle \mathrm{ICF}$, and $\triangle \mathrm{FCF}$. Table 3 shows that the linear regression test's results, where the results show that the hypothesis model is not fit as the significance level of the Fstatistic is (0.097). All indicators ( $\triangle \mathrm{OCF}, \triangle \mathrm{ICF}$, and $\triangle \mathrm{FCF})$ do not have a significant relationship with Jordanian commercial banks' cash dividends. The consistent term of this model is not significant $(\mathrm{Beta}=0.054)$ at $\mathrm{p}$-value $>0.10$. This means that the null hypothesis is accepted.

Table 3. The Regression Result of the H01 Hypothesis - Model (1)

\begin{tabular}{|c|c|c|c|}
\hline \multirow{2}{*}{ Variables } & \multicolumn{3}{|c|}{$\Delta \mathrm{DV} i t=\alpha+\beta_{1} \Delta \mathrm{OCF} i t+\beta_{2} \Delta \mathrm{ICF} i t+\beta_{3} \Delta \mathrm{FCF} i t+\varepsilon_{i t}$} \\
\hline & Coefficients $(\beta)$ & (t-static) & Sig. \\
\hline Cons- & 0.045 & 1.159 & 0.249 \\
\hline$\triangle O C F$ & 0.008 & 0.516 & 0.607 \\
\hline$\Delta I C F$ & 0.001 & 0.031 & 0.975 \\
\hline$\Delta \mathrm{FCF}$ & 0.002 & 0.086 & 0.932 \\
\hline $\boldsymbol{R}($ Beta $)$ & 0.054 & & \\
\hline Adjusted R-Square & -0.027 & & \\
\hline$(F$-value $)$ & 0.097 & & \\
\hline$*, * *, * * *:$ p-value $<$ & $10,0.05,0.01$ & & \\
\hline
\end{tabular}

Source: Authors.

H02: There is no statistically significant effect of liabilities size on the relationship between changes in cash flows and changes in cash dividends for commercial banks operating in Jordan.

This hypothesis investigates the effect of liabilities volume on the relationship between changes in cash flows and changes in cash dividends of Jordanian commercial banks. The results of the linear regression test in Table 4 shows that no effect of liabilities volume on this relationship as the significance level of the Fstatistic (0.119) and p-value $>0.10$. Thereby, the consistent term of this model is not significant $(B e t a=0.069)$. Consequently, the null hypothesis is accepted.

H03: There is no statistically significant relationship between changes in accounting earnings and changes in cash dividends for commercial banks operating in Jordan.

This hypothesis investigates the relationship between changes in accounting earnings and changes in cash dividends of Jordanian commercial banks. The linear regression test in Table 5 shows that the hypothesis model fits at a significance level of the Fstatistic (12.409) and p-value $\leq 0.01$. 
Table 4. The Regression Result of the H02 Hypothesis - Model (2)

\begin{tabular}{|c|c|c|c|}
\hline \multirow[t]{2}{*}{ Variables } & \multicolumn{3}{|c|}{$\Delta \mathrm{DV} i t=\alpha+\beta_{1} \mathrm{Lit}+\beta_{2} \Delta \mathrm{OCF} i t+\beta_{3} \Delta \mathrm{ICF} i t+\beta_{4} \Delta \mathrm{FCF} i t+\varepsilon_{i t}$} \\
\hline & Coefficients $(\beta)$ & $(t$-static) & Sig. \\
\hline Cons- & 0.057 & 0.778 & 0.438 \\
\hline $\mathbf{L}$ & -0.001 & -0.340 & 0.735 \\
\hline Cons- & 0.076 & 0.929 & 0.355 \\
\hline $\mathbf{L}$ & -0.002 & -0.434 & 0.665 \\
\hline$\triangle O C F$ & 0.009 & 0.592 & 0.555 \\
\hline$\triangle I C F$ & 0.001 & 0.042 & 0.967 \\
\hline$\Delta \mathbf{F C F}$ & 0.000 & 0.018 & 0.986 \\
\hline $\boldsymbol{R}($ Beta $)$ & 0.069 & & \\
\hline Adjusted R-Square & -0.035 & & \\
\hline (F-value $)$ & 0.119 & & \\
\hline
\end{tabular}

Source: Authors.

This model's consistent term is significant (Beta=0.329); thereby, there is a significant relationship between changes in accounting earnings and changes in cash dividends of Jordanian commercial banks. Also, accounting earnings changes explain $10.8 \%$ (RSquare $=0.108$ ) of the variance of changes in cash dividends of Jordanian commercial banks. Therefore, the alternative hypothesis is accepted.

Table 5. The Regression Result of the H03 Hypothesis - Model (3)

\begin{tabular}{|c|c|c|c|}
\hline \multirow[t]{2}{*}{ Variables } & \multicolumn{3}{|c|}{$\Delta \mathrm{DV} i t=\alpha+\beta_{1} \Delta \mathrm{ER} i t+\varepsilon_{i t}$} \\
\hline & Coefficients $(\beta)$ & $\overline{(t-\text {-static })}$ & Sig. \\
\hline Cons- & 0.023 & 0.796 & 0.428 \\
\hline$\Delta \mathbf{E R}$ & 0.357 & 3.523 & $0.001 * * *$ \\
\hline$R($ Beta $)$ & 0.329 & & \\
\hline Adjusted R-Square & 0.108 & & \\
\hline (F-value $)$ & 12.409 & & \\
\hline
\end{tabular}

Source: Authors.

HO4: There is no statistically significant effect of liabilities size on the relationship between changes in accounting earnings and changes in cash dividends for commercial banks operating in Jordan.

This hypothesis aims to investigate the effect of liabilities volume on the relationship between changes in accounting earnings and changes in cash dividends of Jordanian commercial banks. Table 6 shows that the hypothesis model is fit at a significance level of the $F$-statistic (6.423) and $p$-value $\leq 0.01$.

The consistent term of this model is significant (Beta=0.336). This means that there is a significant effect of liabilities volume on the relationship between changes in accounting earnings and changes in cash dividends of Jordanian commercial banks. 
In other words, the control variable of liabilities volume improves the beta value (relationship) between changes in accounting earnings and changes in cash dividends of Jordanian commercial banks to be (0.336). Thus, the alternative hypothesis is accepted.

Table 6. The Regression Result of the H04 Hypothesis - Model (4)

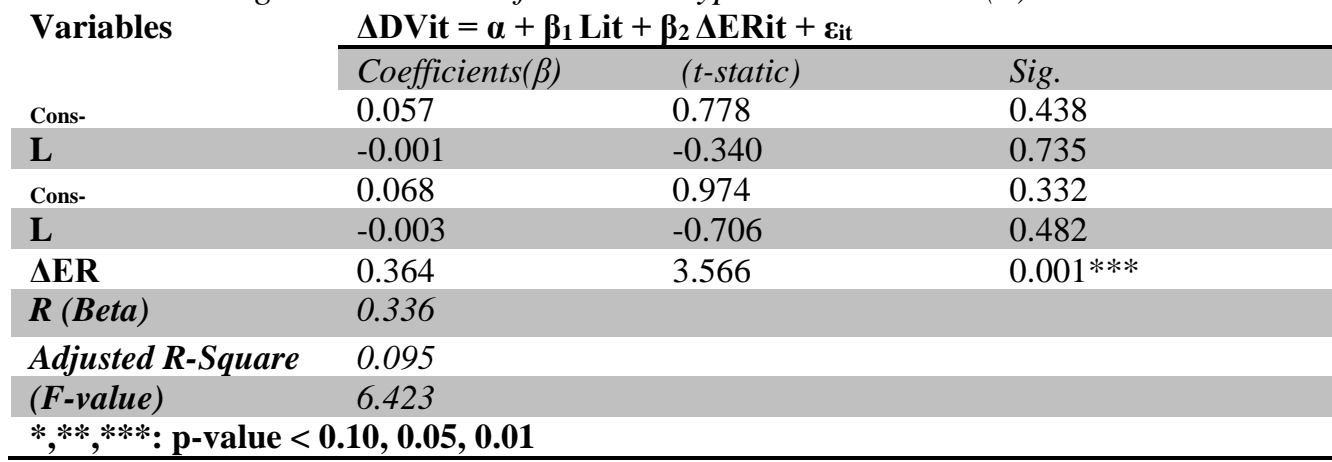

Source: Authors.

\section{Study Conclusions}

The study results conclude that there is no effect of changes in operating, investing, and financing cash flows on cash dividends of commercial banks operating in Jordan. This result is generally consistent with previous studies' results except, for example, Bani-Khaled (2012), who showed a relationship between cash flows and dividends.

According to the researchers' opinion, the main reason for this result is the large fluctuations and instability in cash flows from one financial year to another. This makes it difficult for banks to rely on cash flows to decide dividends for their shares. Also, regardless of the entity that uses the outputs of the cash flows statement, their goals remain the same, which are to know the sources and uses of cash, to show the cash effects for all their activities during the financial period, and to clarify the nature of this cash flow internally and externally. Cash flow indicators are essential to help banks in assessing their financial position, and determining the strengths and weaknesses of their activities, in addition to identifying the degree of their liquidity and financial flexibility, and the degree of risk that accompanies cash flows, but not making decisions regarding the values of cash dividends, where multiple factors other than the availability of cash play a role in determining cash dividends for shares in Jordanian commercial banks. The results also documented a statistically significant relationship between changes in accounting earnings and changes in the value of cash dividends in Jordanian commercial banks. This result agrees with most of the prior studies, especially Al-Rjoub et al. (2013), Kodithuwakku (2016), and Foerster et al. (2017). This confirms the researchers' opinion that cash dividends are affected by multiple factors. Dividend policies depend on the existence of earnings first, the 
availability of cash in the second degree, and bank plans and policies to manage cash to, for example, influence its stock price or opinions of its investors.

Finally, the results point out that the bank's ability to distribute dividends is influenced largely by the size of its liabilities since liabilities in banks particularly represent a large value. This affects their cash dividends policy, as banks tend to withhold a large part of their cash to reserve and pay customers' deposits.

\section{Study Recommendations and Future Research}

The study recommends commercial banks to make a logical link between their cash flows and accounting earnings when paying cash dividends for their shares. Relying on the outputs of the cash flow statement is important in knowing the bank's actual financial situation and its true ability to meet its obligations, and in determining its degree of liquidity as a critical factor when making its dividend decision, in addition to forecasting the bank's ability to pay cash dividends in future. The study results indicate that earnings are considered one of the main factors in determining cash dividends. This result requires commercial banks to be careful that dividend should not negatively affect their retained earnings, internal financing, and capital value in the financial markets.

Finally, the bank's ability to pay cash dividends is largely influenced by the legal rules and restrictions that control the dividend policy, which differs from one country to another; however, banks should link their dividend policy to the size of liabilities, as they are obligated to pay deposits and interest on them when are due; therefore, deposits are considered a basic determinant that should be taken into consideration when making the cash dividend decision, especially when these deposits are long term.

\section{References:}

Al-Habbash, M. 2006. Using cash flow and accounting return metrics to predict future cash flows: An applied study on Palestinian banks, Master Thesis, Islamic University, Gaza, Palestine.

Al-Laban, D., Almshabbk, A., Abdulridha, W. 2018. The role of dividend payout in the determination of the relationship between earnings before interest and tax, cash flow from operations, capital expenditures and firm sustainable cash flows: A case of nonfinancial firms. The Journal of Social Sciences Research, special issue (5), 382-390.

Al-Rjoub, A., Alsharari, N., Al-Qudah, A., Alfawaerah, N. 2013. The relationship between the EPS \& the market stock return (Case study: Industrial sector-Jordan), Information and Knowledge Management, 3 (11), 15-23.

Al-Zahrani, A., Al-Debi'e, M. 2016. Suggested methodologies to improve the returnsearnings relationship (An applied study on Saudi shareholding companies). Jordan Journal of Business Administration, 12(2), 271-288.

Amman Stock Exchange. 2019. Public shareholding companies guide for the year 2019, www.ase.com.jo. 
Atieh A., Hussain, S. 2012. Accounting data and UK dividends. Journal of Applied Accounting Research, 13(1), 56-70.

Bala, S. 2017. The relationship between cash flows and stock returns: An empirical study of financial investment banks on the Khartoum stock of exchange. Applied Finance and Accounting, 3(2), 14-19.

Baltagi, B. 2008. Econometric analysis of panel data, 4th ed., USA: John Wile \& Sons, Inc.

Baltagi, B., Jung, B., Song, S. 2010. Testing for heteroskedasticity and serial correlation in a random effects panel data model. Journal of Econometrics, 154(2),122-124.

Bani-Khaled, M. 2012. Financial crisis, cash flows, and market value per share in the Jordanian commercial banks for the period 2000-2009. Interdisciplinary Journal of Contemporary Research in Business, 4(8), 191-201.

Charitou, A. 2000. The impact of losses and cash flows on dividends: Evidence for Japan. Abacus, 36(2), 198-225.

Curtis, P., Hanias, M., Kourtis, E., Kourtis, M. 2020. Data Envelopment Analysis (DEA) and Financial Ratios: A Pro-Stakeholders' View of Performance Measurement for Sustainable Value Creation of the Wind Energy. International Journal of Economics and Business Administration, 8(2), 326-350. DOI: 10.35808/ijeba/465.

DeAngelo, H., DeAngelo, L., Skinner, D. 1992. Dividends and losses. Journal of Finance, 47(5), 1837-1863.

Dergham, M., Dergham, S. 2009. The relationship between cash flows and stock returns according to International Accounting Standard No. (7): An applied study on national banks operating in Palestine. Arab Journal of Management, 30(2), 45-80.

Fah, C., Mohamad, S. 2008. Are cash flows relevant for stock pricing in Bursa Malaysia? International Journal of Economics and Management, 2(2), 353-367.

Foerster, S., Tsagarelis, J., Wang, G. 2017. Are cash flows better stock return predictors than profits? Financial Analysts Journal, 73(1), 73-99.

Garrison, R., Noreen, E., Brewer, P. 2018. Managerial accounting, 16th ed., New York, McGraw-Hill.

Gujarati, D., Porter, D. 2009. Basic Econometrics, 5th ed., New York, McGraw-Hill.

Hafsi, R. 2017. Study and analysis of the influences of the dividend policy on shares performance of companies listed on the financial market (Case of Dubai Financial Market 2011-2014). Algerian Journal of Accounting and Financial Studies, (2), 39-52.

Hamidi, K. 2014. The effect of operational cash flows on the company value: An applied study in a sample of private Iraqi banks listed on the Iraq Stock Exchange. Almuthanna Journal of Administrative and Economic Sciences, 3(7), 64-87.

Hortamani, A., Tavakoli, B. 2015. The relationship between shares market value and the return of assets, cash flow and net operating income. Academie Royale Des Sciences D Outre-Mer Bulletin Des Seances, 4(2), 16-20.

Kaddumi, T., Al-Kilani, Q. 2006. The use of cash flow statement to evaluate the financial performance of Jordanian industrial corporations: An analytical study of a sample of Jordanian public shareholding industrial companies (2000-2003). Jordan Journal of Applied Sciences, 8(1), 112-132.

Kadioglu, E., Yilmaz, E. 2017. Is the free cash flow hypothesis valid in Turkey? Borsa Istanbul Review, 17(2), 111-116.

Khanji, I., Siam, A. 2015. The effect of cash flow on share price of the Jordanian commercial banks listed in Amman Stock Exchange. International Journal of Economics and Finance, 7(5), 109-115. 
Kodithuwakku, S. 2016. Impact of firm specific factors on the stock prices: A case study on listed manufacturing companies in Colombo Stock Exchange. International Journal for Research in Business, Management and Accounting, 2(3), 67-76.

Kourtis, E., Kourtis, G., Curtis, P. 2019. An Integrated Financial Ratio Analysis as a Navigation Compass through the Fraudulent Reporting Conundrum: A Case Study. International Journal of Finance, Insurance and Risk Management, 9(1-2), 3-20. DOI: $10.35808 / \mathrm{ijfirm} / 187$.

Nazemi, H., Abdoli, M. 2015. The relationship of stock return with earnings and cash flows before and after financial statement restatements by the companies listed on the Tehran Stock Exchange. European Online Journal of Natural and Social Sciences, 4(1), 75-79.

Ningsih, L., Soesetio, Y. 2018. How do free cash flow and dividend policy affect stock return? 1st International Research Conference on Economics and Business, KnE Social Sciences, 11-12 December, Indonesia, 333-343.

Olugbenga, A., Atanda, O. 2014. The relationship between financial accounting information and market values of quoted firms in Nigeria. Global Journal of Contemporary Research in Accounting. Auditing and Business Ethics, 1(1), 22-39.

Oroud, Y., Islam, M., Tunku, S. 2017. The effect of cash flows on the share price on Amman Stock Exchange, American Based Research Journal, 6(7), 22-28.

Rose, P. 2003. Money and capital markets, 8th ed., New York, McGraw Hill.

Sharma, D., Iselin, E. 2003. The relative relevance of cash flow and accrual information for solvency assessments: A multi-method approach, Journal of Business Finance \& Accounting, 30(7-8), 1115-1140.

Sindhu, M. 2014. Relationship between free cash flow and dividend: Moderating role of firm size. Research Journal of Finance and Accounting, 5(5), 16-23.

Tijjani, B. 2016. An empirical analysis of free cash flow and dividend policy in the Nigerian oil and gas sector. Research Journal of Finance and Accounting, 7(12), 154-160.

Yamrali, O., Nezhad, A., Hivehchi, E. 2014. The relationship between the operational profit, operational cash flow and abnormal returns in initial public offering in Tehran Stock Exchange. Technical Journal of Engineering and Applied Sciences, 4(2), 53-59.

Yeo, H. 2018. Role of free cash flows in making investment and dividend decisions: The case of the shipping industry. The Asian Journal of Shipping and Logistics, 34(2), 113 118. 